\title{
Evaluation Outcomes Associated with Alternative Dosing Strategies for Piperacillin/Tazobactam: A Systematic Review and Meta-Analysis
}

\author{
Hui Yang, Xiangli Cui, Zhuo Ma, Lihong Liu \\ Beijing Chao-Yang Hospital, Capital Medical University, Beijing, China. \\ Received, March 25, 2016; Revised, June 13, 2016; Accepted, July 4, 2016; Published, July 7, 2016.
}

\begin{abstract}
A better dosing strategy can improve clinical outcomes for patients. We systematically reviewed the literatures to determine whether any clinical benefits exist for piperacillin/tazobactam by extended or continuous infusion. Methods - A search of PubMed, Web of Science, ProQuest, ScienceDirect, Cochrane, Embase and related ICAAC and ACCP conferences were conducted up to September 5, 2015. Randomized controlled and observational studies that compared extended or continuous infusion with conventional intermittent infusion of piperacillin/tazobactam were identified from the databases above and analyzed. Two reviewers independently evaluated the methodology and extracted data from primary studies. A meta-analysis was performed using Revman 5.2 software. The quality of each study was assessed. Sensitivity analysis and publication bias were evaluated. Results - Three randomized controlled trials and twelve observational studies were included in this study. All included studies had high quality and no publication bias was found. Compared to the conventional intermittent infusion approach, the extended or continuous infusion group had a significant cost effectiveness (OR -0.89.02, CI $(-114.69,-63.35), \mathrm{P}<0.00001)$. No statistical difference was observed for clinical cure rate $(\mathrm{OR} 1.64,95 \% \mathrm{CI}(0.88,3.30), \mathrm{P}=0.12)$ between the two dosing regimens. The sensitivity analysis showed the results were stable. Conclusions - Our systematic review and meta-analysis found that the outcomes associated with alternative dosing strategies of piperacillin/tazobactam have changed compared with conclusions before for several literatures with large samples published. Further data on the outcomes should be generated for a better understanding of the extended or continuous infusion strategy. On the whole, our meta-analysis suggested that the extended or continuous infusion should be recommended for clinical use only considering its economic advantage, but there was no significantly higher clinical cure rate and lower mortality rate compared with the conventional intermittent infusion.
\end{abstract}

This article is open to POST-PUBLICATION REVIEW. Registered readers (see "For Readers") may comment by clicking on ABSTRACT on the issue's contents page.

\section{INTRODUCTION}

As more is understood about antimicrobial agents through research, it is evidenced that proper use of antimicrobials can improve clinical outcomes and reduce resistance, while maintaining antimicrobial sensitivity in general population (1)-(4). Piperacillin/tazobactam is a broad class of antibiotics commonly used to successfully treat bacterial infections (5)-(6). Conventional dosing strategy of piperacillin/tazobactam is an intermittent 30-minute infusion, potentially resulting in serum concentrations below minimum inhibitory concentration (MIC) for a prolonged period of time (7). As a time-dependent antibiotic, the bactericidal activity of piperacillin/tazobactam is optimized when drug concentrations exceed the fractional time above the minimum inhibitory concentration (fT $>$ MIC) for at least $30 \%$ to $50 \%$ (8)-(9). Several studies have consistently demonstrated that continuous infusion allows the maintenance of concentrations above the MIC for a longer period of time within the dosing interval (10)-(11).Two metaanalyses have been conducted to compare the clinical outcomes of patients who received prolonged or continuous infusions versus conventional intermittent infusions (12)-(13). According to the latest understanding, the extended or continuous infusion of piperacillin/tazobactam led to a higher clinical cure rate and a lower mortality rate than the conventional intermittent strategy (13). However, many new studies with large samples have been published recent years (14)-(16). Therefore, it is important and necessary to systematically investigate the clinical outcome differences between the two dosing strategies of piperacillin/tazobactam from those clinical trials in order to produce an evidence-based recommendation for which strategy is better for clinical practice.

Corresponding Author: Lihong Liu, Pharmacy Department of Beijing Chao-Yang Hospital, 8 Gongren Tiyuchang Nanlu, Chaoyang District, Beijing, China; Email: hongllh@126.com. 


\section{METHODS}

\section{Literature search}

Relevant English language studies included in this review were identified from PubMed, Web of Science, ProQuest, ScienceDirect, Cochrane and related Interscience Conference on Antimicrobial Agents and Chemotherapy (ICAAC) and American College of Clinical Pharmacology ( ACCP ) conferences databases. Databases were searched from inception up to September 5, 2015 using combinations of the following search terms: (piperacillin/tazobactam) AND (extended OR continuous OR prolonged OR intermittent OR discontinuous OR short OR traditional OR conventional OR intermittent) AND (duration OR infusion OR administration OR interval OR dosing).

\section{Study selection}

Articles reporting the comparative outcomes of patients treated with the two different dosing strategies of piperacillin/tazobactam were eligible for the meta-analysis, and the types of studies included were prospective study, retrospective study and randomized controlled trials (RCT). Two authors (H.Y and Z.M) independently screened titles and abstracts identified by the search process. Afterward, all full text articles from potentially eligible studies were retrieved and independently reviewed by the same authors using the aforementioned inclusion criteria. Any disagreement was resolved by discussion and in consensus with the principal author (X.L.C and L.H.L).

\section{Quality assessment}

Independent evaluation of methodological quality was performed by two reviewers (H.Y and Z.M). Discrepancies were resolved by involvement of a third review author (X.L.C) if required. RCTs were appraised for methodological quality using the criteria developed by the Cochrane risk of bias tool: random sequence generation, allocation concealment, blinding of participants and personnel, blinding of outcome assessment, incomplete outcome data, selective reporting and other bias. The Newcastle-Ottawa Scales (NOS) was used to assess the quality of observational studies (17).

\section{Data extraction}

Two reviewers (H.Y and Z.M) independently extracted relevant information for the meta-analysis. The following data were extracted from each study: the characteristics of each study (author, study design, years, country), patient population (numbers of patients, type and etiology of infection), drug regimens, and clinical outcomes (clinical cure, mortality, days in hospital, cost) of the two groups in each study. And clinical cure was defined as "cure" (the complete resolution of clinical signs and symptoms of infection, with no new signs or symptoms associated with the original infection) or "improvement" (the patient was not cured, but there was a resolution or a reduction of the majority of the clinical signs and symptoms of infection and no new or worsened signs associated with the original infection) in these studies. Days in hospital were directly described instead of statistical analysis considering different data expression.

\section{STATISTICAL ANALYSIS}

Analyses were performed using Review Manager for Windows (version 5.2). Odds ratio (OR) and 95\% confidence interval (CI) were calculated for each outcome. The presence of heterogeneity between trials was assessed by $\chi 2$ test. A P-value of $<0.10$ was defined to note statistical significance in the analysis of heterogeneity. The extent of the inconsistencies was characterized using the $I^{2}$ statistic. Considerable heterogeneity was indicated by $I^{2}>50 \%$. MantelHaenszel fixed effects model (FEM) was used when there was no significant heterogeneity between studies; otherwise, a random effects model was chosen. Adverse events were directly described instead of statistical analysis considering few sample sizes included. In order to evaluate the stability of results without estimation bias from individual study, sensitivity analysis was performed by exclusion of each study one by one. This process of excluding one study at a time allowed for identification of any single article that may have a large influence on the final results. Publication bias was assessed using the funnel plot method, of which funnel plot asymmetry was assessed by Egger's linear regression test (18).

\section{RESULTS}

\section{Literature search}

A total of 15 studies with 4847 patients were identified that were eligible for inclusion in the meta-analysis. The whole literature search process is summarized in Figure 1.

\section{Study description}

The characteristics of the eligible studies are presented in Table 1. This meta-analysis included fifteen studies, among which were two prospective studies (19),(20), ten retrospective studies (14)-(16), (21)-(27) and three RCTs (28)-(30). The patients of five of the included studies were persons who were admitted to the Intensive Care Unit (ICU) with severe infection, and the other nine studies included 
only non-ICU patients with moderate or severe infection. Overall, 4847 patients were included in the analysis in the identified studies. In the included studies, conventional intermittent infusion regimens were $2.25-4.5 \mathrm{~g}$ over 20 or $30 \mathrm{~min}$ three or four times daily. The extended infusion regimens lasted greater than 3 hours and the continuous infusion regimens lasted 24 hours with the doses ranging from 6.75 to $13.5 \mathrm{~g}$ daily.

\section{Quality of included studies}

Seven factors were used to evaluate the bias of the three RCT studies according to the Cochrane risk of bias tool. Most factors for all studies showed low bias. However, the method used to generate the allocation sequence in the RCT was not considered adequate, and allocation concealment was not described. On the whole, the included RCTs in our study were of relatively high quality (Supplementary Figure 1 and Supplementary Figure 2).

Included observational were of high quality. Eight factors were used to assess study quality according to NOS. The more factors the study met, the higher the quality of the study was. All studies were adequate in all criteria. The results showed that all observational studies were high quality (Supplementary Table 1).

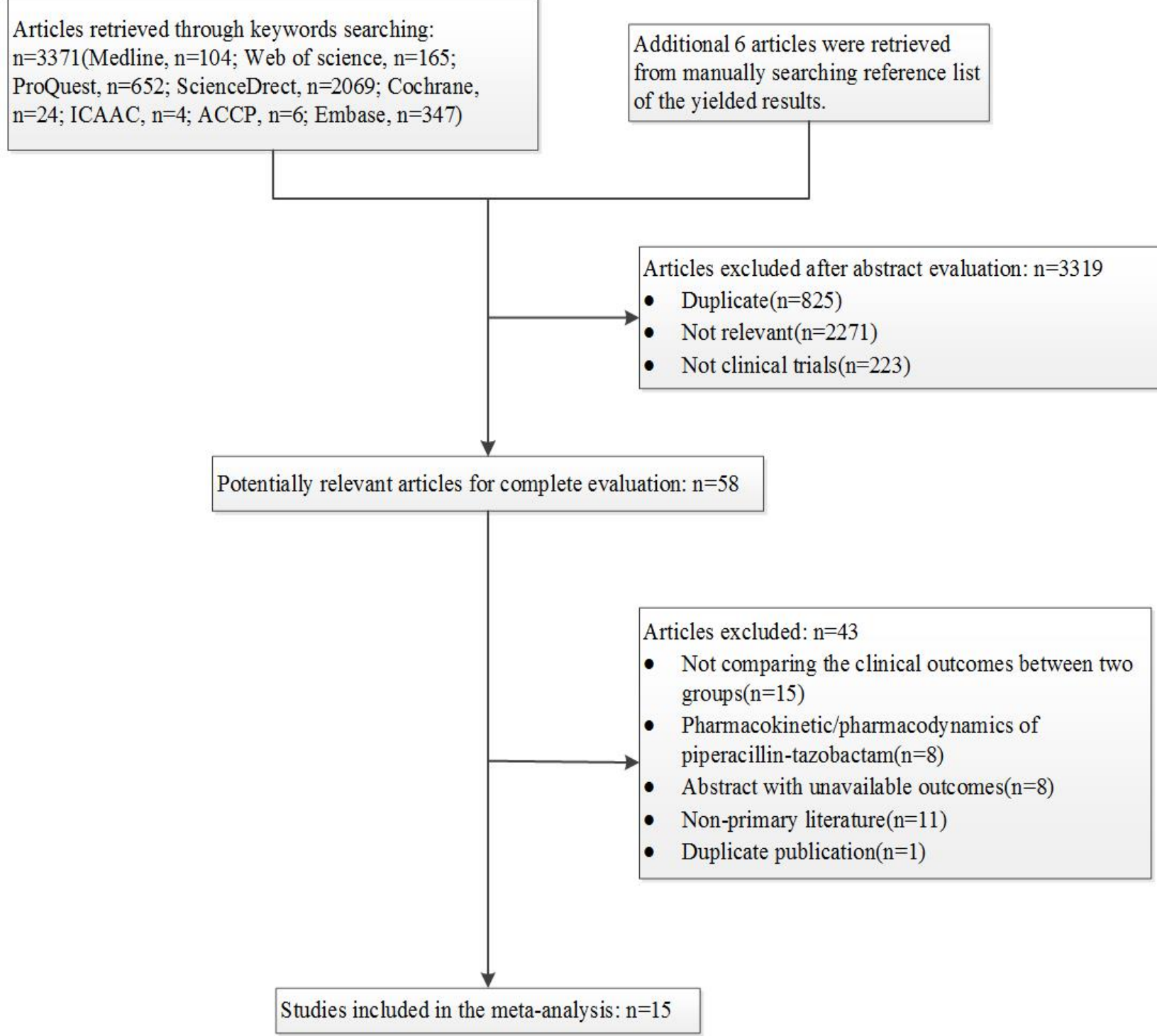

Figure 1. Flow chart depicting the selection process of studies included in the meta-analysis. 


\section{Clinical cure}

Pooled outcomes of 7 studies reported clinical cure rate (19),(20),(23),(24),(14),(28),(30). Compared to the conventional intermittent infusion, the extended or continuous infusion had no significantly higher clinical cure rate (872 patients, OR $1.02,95 \% \mathrm{CI}$ 0.47-2.26, $\mathrm{P}=0.12$; Figure 2). Significant heterogeneity was found among all the studies $\left(\mathrm{I}^{2}=51 \%, \mathrm{P}=0.07\right)$. Subgroup analyses also indicated no statistical difference in clinical cure rate between the two infusion strategies. The funnel plot did not show obvious asymmetry, and there was no publication bias presented by Egger's test $(\mathrm{P}=0.440)$.

\section{Mortality}

Pooled outcomes of twelve studies, including two RCTs showed there was a statistically significant mortality advantage to extended or continuous infusion (OR $0.61, \quad \mathrm{CI}(0.67,0.99)$, $\mathrm{P}=0.04)(14),(16)(19),(21)-(27),(28)-(29) . \quad$ No significant heterogeneity was found among the studies $\left(\mathrm{I}^{2}=44 \%, \mathrm{P}=0.06\right)$. Results of subgroup analyses are displayed in Figure 3. Stratification by study design showed that a mortality benefit was only associated with extended or continuous infusion in observational studies (OR 0.82, CI ( 0.67 , 1.00 ), $\mathrm{P}=0.05$ ) but not in RCTs (OR 0.60, $\mathrm{CI}(0.19,1.93), \mathrm{P}=0.39)$. Obvious asymmetry was not found in the funnel plot. Egger's test showed no publication bias, and the $p$ value was 0.420 , which indicated no statistically significant difference. The results of sensitivity analysis showed substantial modification of the estimates after exclusion of individual study one by one which showed that the result was not reliable.

\section{Cost}

Pooled outcomes of three studies showed a statistically significant difference in healthcare costs between the two infusion strategies (2298 patients, OR -89.02, 95\%CI (-114.69,-63.35), $\mathrm{P}<0.00001$, Figure 4)(16),(19),(30). Subgroup analyses showed that extended or continuous infusion group had a significantly cost benefit in cohort studies subgroup $(\mathrm{OR}=-83.24,95 \% \mathrm{CI}(-109.66,-63.35), \mathrm{P}<0.00001$, Figure 4) and in RCT subgroup (OR $=-187.23$, 95\% CI(-296.18,-78.28), P = 0.009; Figure 3). No significant heterogeneity was found among the studies $\left(\mathrm{I}^{2}=43 \%, \mathrm{P}=0.17\right)$. The results of sensitivity analysis showed no substantial modification of the estimates after exclusion of individual study one by one.

\section{Length of hospital stay}

Twelve of fifteen studies reported length of hospital stay (14)-(16),(19),(21)-(23),(25)-(27),(29)-(30). Seven studies reported length of stay by median, while the others used average. Grant et al reported that days of therapy were similar with both treatment groups ( $7.3 \pm 4.8$ days for continuous infusion versus $8.7 \pm 7.1$ days for conventional intermittent infusion, $\mathrm{P}=0.26$ ) (19). This finding was also found by other eight studies. However, Lodise et al (18), Lee et al (27) and Lu et al (30) reported that length of hospital stay was significantly shorter for patients who received extended or continuous infusion.

\section{DISCUSSION}

The purpose of this study was to conduct an updated review of these studies and to identify whether there is a clinical benefit of extended or continuous infusion on clinical cure rate, mortality, and economic benefit over cost. Our meta-analysis, including fifteen studies (two prospective studies, ten retrospective studies, and three RCTs), showed that the extended or continuous infusion strategy was associated with economic benefits compared with the conventional intermittent approach. The clinical cure rate and mortality were not significantly different between the two dosing approaches. The severity of infection was not included as part of the result analysis among these studies, but the average level of severity of infection between two dosing groups for each study was not significantly different.

Higher clinical cure rate for the extended or continuous infusion approach was not found in our study, which was in line with Falagas et al' research published in 2013 (12), but was contrary to the research of Yang et al in 2014 (13). Many new studies with better study design and larger samples have been published since April 2014 (14)-(16). A total of 1275 patents were included in the Cutro et al' analysis published in 2014 (14). Clinical cure rates were almost identical between extended infusion and conversional infusion, $18.4 \%$ versus $19.9 \%$ for all patients $(\mathrm{P}=0.756)$ in Cutro et al' study. This is the study with the largest sample size comparing different dosing protocols by the end of the 2014 . This article made an impact on the final outcome of clinical cure rate. Subgroup analysis were made, which was not included in the study published by Yang, 2014 (13). The subgroup analyses showed that extended or continuous infusion had no significantly impact on clinical cure rate in the cohort studies subgroup or in the RCT subgroup. Sensitivity analysis is used to measure the stability of the results, and it did not modify the conclusion of the study when excluded during the sensitivity analyses.

Our meta-analysis only found that extended or continuous infusion was not worse to conventional 
infusion. The result showed that mortality was lower among patients who received extended or continuous infusion of the piperacillin/tazobactam, but stratification by study design showed that a mortality benefit was only associated with extended or continuous infusion in observational studies but not in RCTs. In addition, sensitivity analysis showed substantial modification of the estimates after exclusion of individual study one by one, which indicates that the result was not reliable. All in all, we cannot reach the conclusion that extended or continuous infusion of piperacillin/tazobactam resulted in significantly lower mortality rate compared with the conventional intermittent infusion. Our result differs from the published articles in 2013 and 2014 (12)-(13). We conclude that the two studies included in our meta-analysis with large sample size led to different result. No significant differences between the extended infusion or continuous infusion and conversional infusion in inpatient mortality rates $(10.9 \%$ versus $13.8 \% ; \mathrm{P}=0.282$ ) in Cutro et al' research in 2014 (14). Brunetti et al found that 14-day in-hospital mortality was similar between groups in 2150 patents in $2015(\mathrm{OR}=1.16 ; 95 \% \mathrm{CI}=0.85-1.58$; $\mathrm{P}=0.37$ ) (16). To our knowledge, the two studies were the largest sample size up till today comparing the two dosing strategies. This might explain the difference between the results.

This article is the first meta-analysis finding that the extended or continuous infusion of antibiotics is associated with economic benefits. Study suggested that extended or continuous infusion of piperacillin/tazobactam was more cost-effective than conversional infusion. The potential economic benefits might be attributed to lower cost of antibiotics acquisition as showed in studies that used lower doses in patients with extended infusion or fewer days of ICU or hospital stay (31)-(32). There were only three studies that included in economic analysis. More well-designed trials are needed to clarify this issue.

All studies that we analyzed were of high quality, including RCTs and observational studies. Therefore, our conclusions were relatively reliable, but the findings of this meta-analysis should be interpreted in view of certain limitation. First, only 3 of 15 of the included studies were RCTs, where small sample size might introduce bias. Additionally, information regarding concurrent medications was not released in the studies analyzed. Therefore, drug interactions were unknown and could not be evaluated in our analysis. Also, disease status and drug doses were not the same in all studies, which could influence the clinical outcomes.

In conclusion, evidence demonstrated that the extended or continuous infusion of piperacillin/tazobactamis associated with significant cost savings than the conventional intermittent strategy. Therefore, this alternative infusion strategy could be recommended in clinical practices. Further data should be generated for a better understanding of the extended or continuous infusion strategy.

\section{ACKNOWLEDGEMENTS}

We thank all the original authors of the included studies for their wonderful work.

\section{AUTHOR CONTRIBUTION}

The experiments were designed by LHL and performed by HY and XLC. The data were analyzed by HY and ZM. The manuscript was written by HY and revised by ZM, XLC and LHL.

\section{REFERENCE}

1. Fehér C, Rovira M, Soriano A, et al. Effect of meropenem administration in extended infusion on the clinical outcome of febrile neutropenia: a retrospective observational study. J Antimicrob Chemother, 69: 2556-62, 2014.

2. Felton TW1, Goodwin J, O'Connor L, et al. Impact of Bolus dosing versus continuous infusion of Piperacillin and Tazobactam on the development of antimicrobial resistance in Pseudomonas aeruginosa. Antimicrob Agents Chemother, 57: 5811-9, 2013.

3. Bauer KA, West JE, O'Brien JM, et al. Extendedinfusion cefepime reduces mortality in patients with Pseudomonas aeruginosa infections. Antimicrob Agents Chemother, 7: 2907-12, 2013.

4. Thalhammer F, Traunmüller F, El Menyawi I, et al. Continuous infusionversus intermittent administration of meropenem in critically ill patients. J AntimicrobChemother,43: 523-7, 1999.

5. Mah GT, Mabasa VH, Chow I, et al. Evaluating outcomes associated with alternative dosing strategies for piperacillin/tazobactam: a qualitative systematic review. Ann Pharmacother, 46: 265-75, 2012.

6. Solomkin JS, Mazuski JE, Bradley JS, et al. Diagnosis and management of complicated intraabdominal infection in adults and children: guidelines by the Surgical Infection Society and the Infectious Diseases Society of America. Clin Infect Dis, 5: 133-64, 2010.

7. De Waele JJ, Carrette S, Carlier M, et al. Therapeutic drug monitoring-based dose optimisation of piperacillin and meropenem: a randomized controlled trial. Intensive Care Med,40: 380-7, 2014.

8. Javad A, Vahid P, Kazem G, et al. Piperacillin/tazobactam in treatment of brain abscess. Scand J Infect Dis,38: 224-6, 2006.

9. Roberts JA, Paratz J, Paratz E, et al. Continuous 
infusion of beta-lactam antibiotics in severe infections: a review of its role. Int $\mathrm{J}$ Antimicrob Agents,30: 11-8, 2007.

10. BenkoAS, CappellettyDM, KruseJA, et al. Continuous infusion versus intermittent administration of ceftazidime in critically ill patients with suspected Gram-negativeinfections. Antimicrob Agents Chemother, 40: 691-5, 1996.

11. LanggartnerJ, VasoldA, GluckT, et al. Pharmacokinetics of meropenem during intermittent and continuous intravenous application in patients treated by continuous renal replacement therapy. Intensive Care Me, 34: 1091-6, 2008.

12. Falagas ME, Tansarli GS, Ikawa K, et al. Clinical outcomes with extended or continuous versus shortterm intravenous infusion of carbapenems and piperacillin/tazobactam: a systematic review and meta-analysis. Clin Infect Dis,56: 272-82, 2013.

13. Hui Yang, Chao Zhang, Quanyu Zhou, et al. Clinical Outcomes with Alternative DosingStrategies for Piperacillin/Tazobactam: A Systematic Review and Meta-Analysis. PLoS One, 10: e0116769, 2015.

14. Cutro SR, Holzman R, Dubrovskaya Y, et al. Extended-Infusion versus standard-infusion piperacillin-tazobactam for sepsis syndromes at a tertiary medical center. Antimicrob Agents Chemother, 58: 4470-5, 2014.

15. McCormick $\mathrm{H}$, Tomaka $\mathrm{N}$, Baggett $\mathrm{S}$, et al. Comparison of acute renal injury associated with intermittent and extended infusion piperacillin/tazobactam. Am J Health Syst Pharm, 72: S25-30, 2015.

16. Brunetti L, Poustchi S, Cunningham D, et al.Clinical and Economic Impact of Empirical ExtendedInfusion Piperacillin-Tazobactam in a Community Medical Center. Ann Pharmacother, 49: 754-60, 2015.

17. GA Wells, B Shea, D O'Connell, et al. The Newcastle-Ottawa Scale (NOS) for assessing the quality of nonrandomized studies in meta-analyses. Available:

http://www.ohri.ca/programs/clinical epidemiology loxford.htm. Accessed 20 September 2015.

18. Egger M, Davey Smith G, Schneider M, et al. Bias in meta-analysis detected by a simple, graphical test. BMJ,315: 629-34, 1997.

19. Grant EM, Kuti JL, Nicolau DP, et al. Clinical efficacy and pharmacoeconomics of a continuousinfusion piperacillin-tazobactam program in a large community teaching hospital. Pharmacotherapy, 22: 471-83, 2002.

20. Buck C, Bertram N, Ackermann T, et al. Pharmacokinetics of piperacillin-tazobactam: intermittent dosing versus continuous infusion. Int $\mathrm{J}$ Antimicrob Agents25: 62-7, 2005.

21. Lodise TP, Lomaestro B, Drusano GL. Piperacillintazobactam for Pseudomonas aeruginosa infection: clinical implications of an extended-infusion dosing strategy. Clin Infect Dis,44: 357-63, 2007.

22. Patel GW, Patel N, Lat A, et al. Outcomes of extended infusion piperacillin/tazobactam for documented gram-negative infections. DiagnMicrobiol Infect Dis, 64: 236-40, 2009.

23. Lorente L, Jiménez A, Martín MM, et al. Clinical cure of ventilator-associated pneumonia treated with piperacillin/tazobactam administered by continuous or intermittent infusion. Int J Antimicrob Agents, 33: 464-8, 2009.

24. Roberts JA, Kirkpatrick CM, Roberts MS, et al. First dose and steady-state population pharmacokinetics and pharmacodynamics of piperacillin by continuous or intermittent dosing in critically ill patients with sepsis. Int J Antimicrob Agents,35: 156-63, 2010.

25. Yost RJ, Cappelletty DM. The retrospective cohort of infusion piperacillin/tazobactam (RECEIPT) study: a multicenter study. Pharmacotherapy,31: 767-75, 2011.

26. Gonçalves-Pereira J, Oliveira BS, Janeiro S, et al. Continuous infusion of piperacillin/tazobactam in septic critically ill patients--a multicenter propensity matched analysis. PLoS One, 7: e49845, 2012.

27. Lee GC, Liou H, Yee R, et al. Outcomes of extendedinfusion piperacillin-tazobactam: a retrospective analysis of critically ill patients. ClinTher,34: 2297300, 2012.

28. Lau WK, Mercer D, Itani KM, et al. Randomized, open-label, comparative study of piperacillintazobactam administered by continuous infusion versus intermittent infusion for treatment of hospitalized patients with complicated intraabdominal infection. Antimicrob Agents Chemother, 50: 3556-61, 2006.

29. Rafati MR, Rouini MR, Mojtahedzadeh M, et al. Clinical efficacy of continuous infusion of piperacillin compared with intermittent dosing in septic critically ill patients. Int J Antimicrob Agents, 28: 122-7, 2006.

30. Lü Y, Yan Z, Wang DH, Dong WL, et al. Treatment study of hospital acquired pneumonia by optimizing dosing regimen of pipercillin / tazobactam : prolonged vs regular infusion. Chin Crit Care Med,25: 479-83, 2013.

31. Dow RJ, Rose WE, Fox BC, et al. Retrospective studyof prolonged versus intermittent infusion piperacillin-tazobactam and meropenem in intensive care unit patients at an academic medicalcenter. Infect Dis Clin Pract, 19: 413-7, 2011.

32. Wang D. Experience with extended-infusion meropenem in the management of ventilatorassociated pneumonia due to multidrug resistant Acineto bacter baumannii. Int J Antimicrob Agents, 33: 290-1, 2009. 


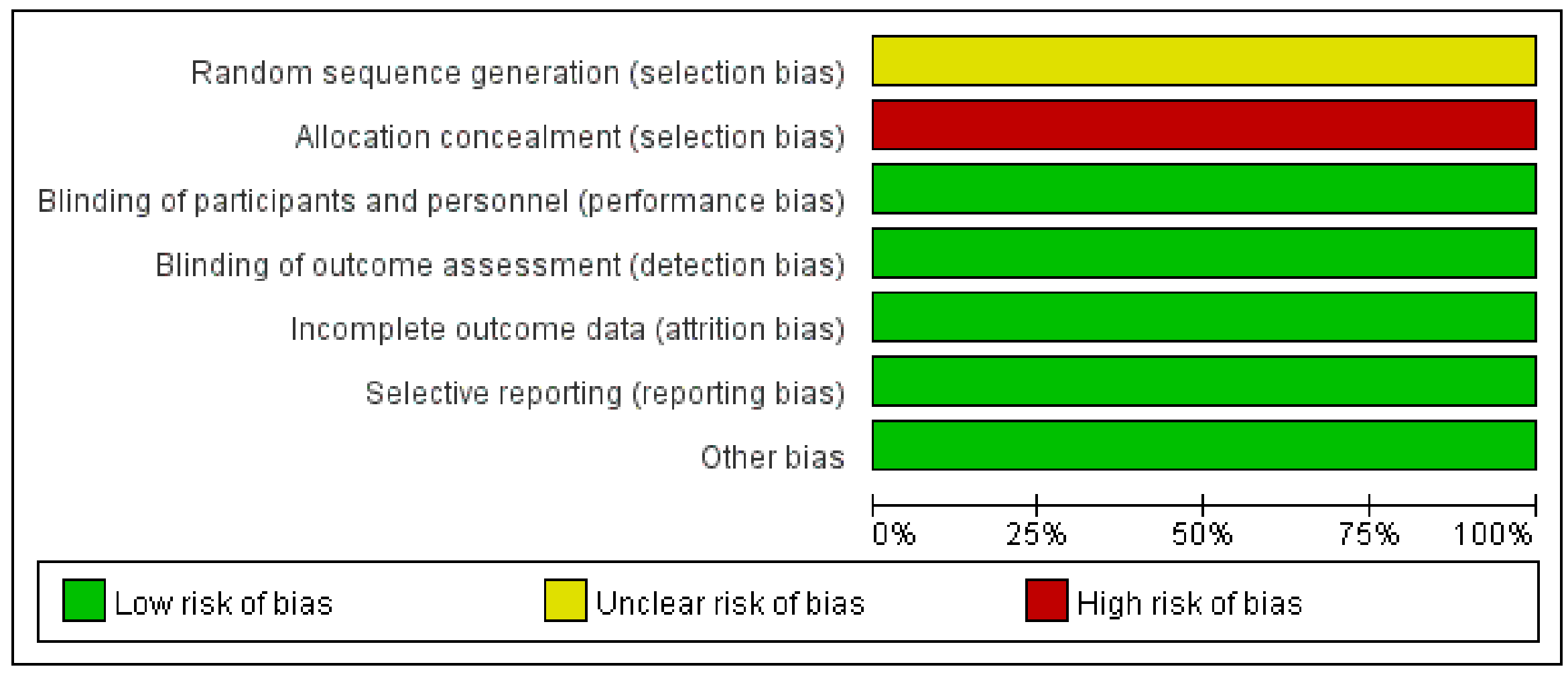

Supplementary Figure 1. Risk of bias summary 
J Pharm Pharm Sci (www.cspsCanada.org) 19(2) 274 - 289, 2016

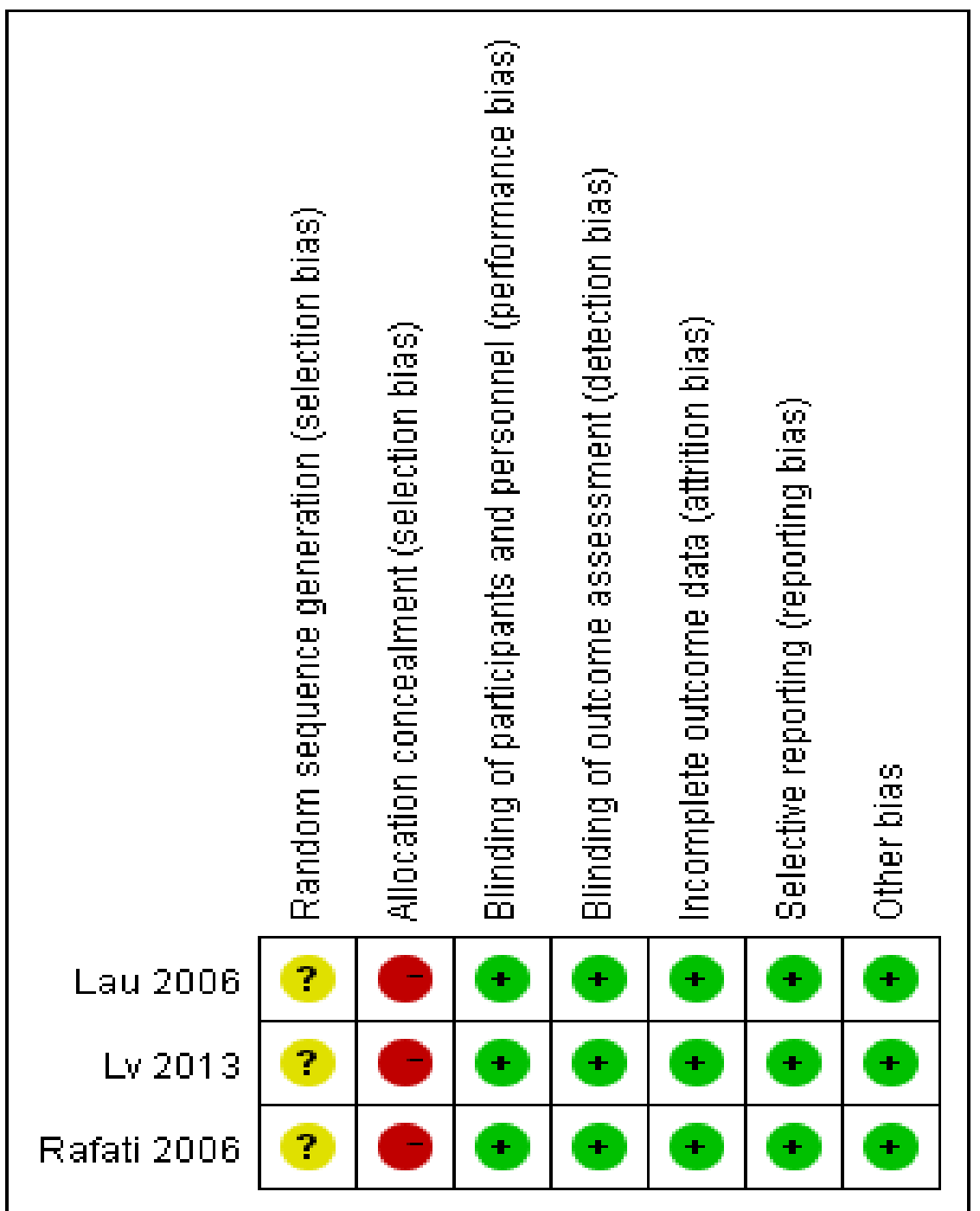

Supplementary Figure 2. Risk of bias graph 


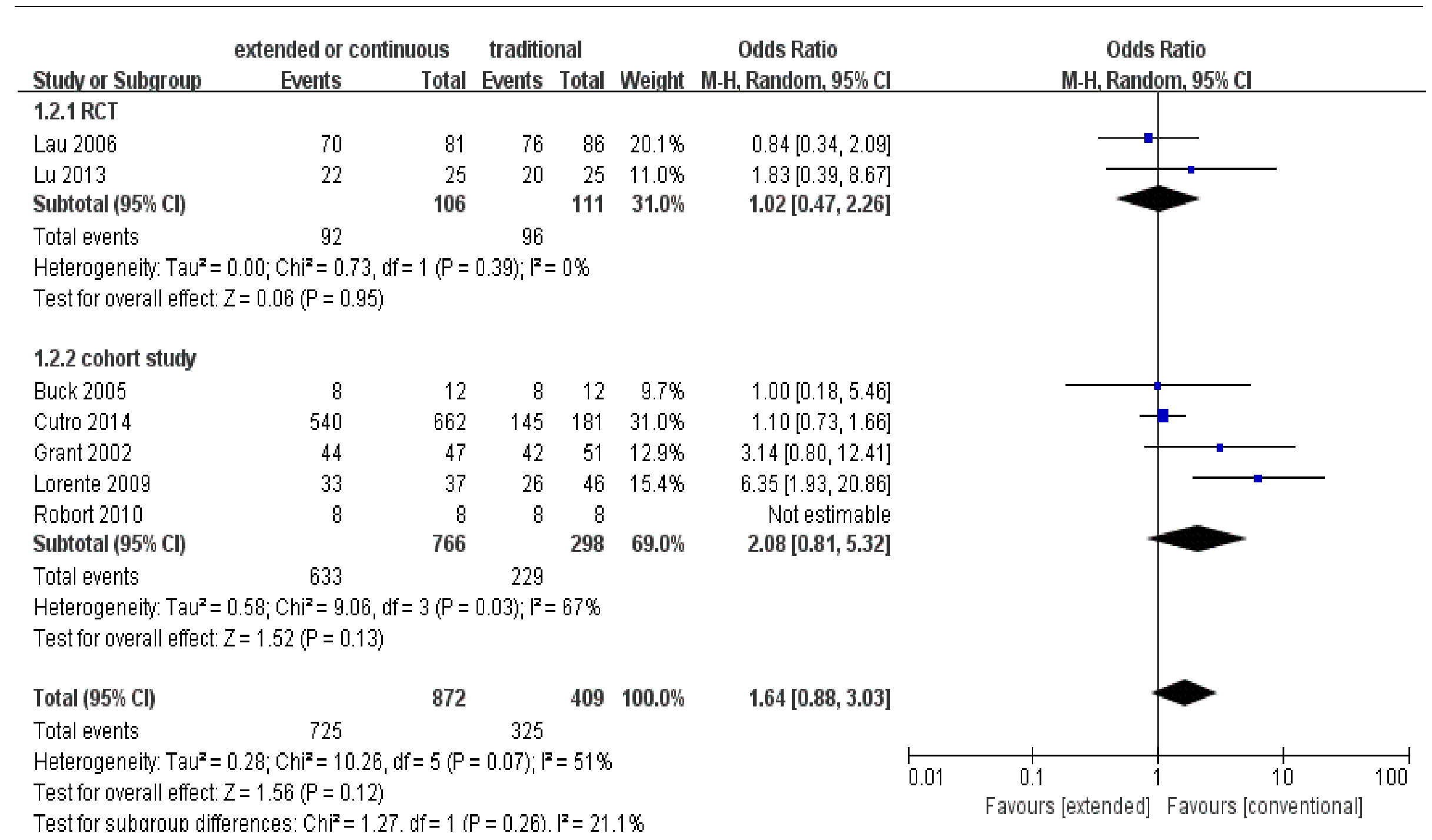

Figure 2. Forest plot depicting the odds ratios of clinical cure of patients receiving extended or continuous versus conventional intermittent infusion of piperacillin/tazobactam. 
J Pharm Pharm Sci (www.cspsCanada.org) 19(2) 274 - 289, 2016

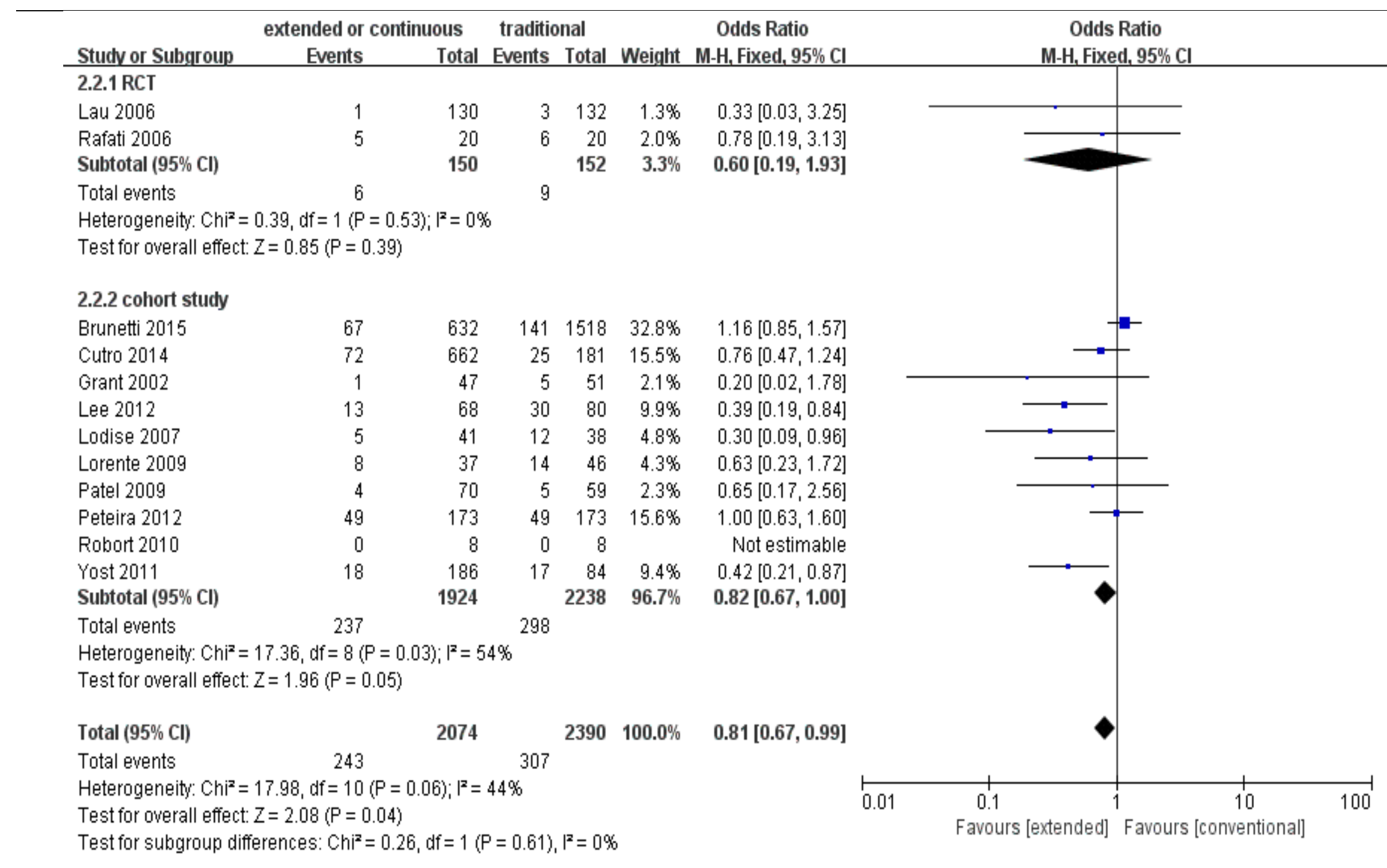

Figure 3. Forest plot depicting the odds ratios of mortality of patients receiving extended or continuous versus conventional intermittent infusion of piperacillin/tazobactam. 
J Pharm Pharm Sci (www.cspsCanada.org) 19(2) 274 - 289, 2016

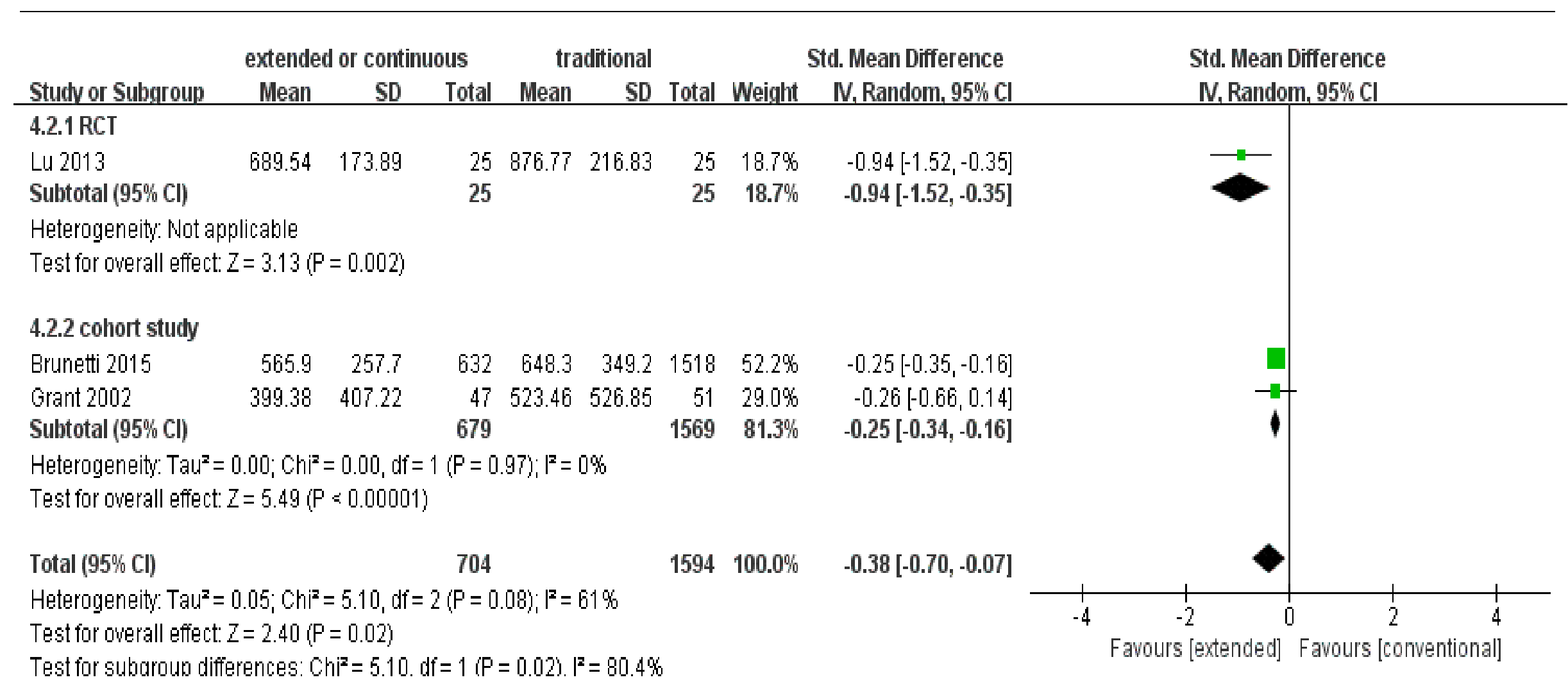

Figure 4. Forest plot depicting the odds ratios of cost of patients receiving extended or continuous versus conventional intermittent infusion of piperacillin/tazobactam. 
J Pharm Pharm Sci (www.cspsCanada.org) 19(2) 274 - 289, 2016

Supplementary Table 1. Quality of observational studies (indicators from New-Castle-Ottawa scale)

\begin{tabular}{|c|c|c|c|c|c|c|c|c|c|c|}
\hline Study & $1 \mathbf{a}$ & $2 \mathbf{b}$ & $3 c$ & 4d & 5Ae & 5Bf & 6g & $7 \mathrm{~h}$ & $8 \mathbf{i}$ & Total quality scores \\
\hline Grant 2002 & Yes & Yes & Yes & Yes & Yes & Yes & Yes & Yes & Yes & 9 \\
\hline Buck 2005 & Yes & Yes & Yes & Yes & Yes & Yes & Yes & Yes & Yes & 9 \\
\hline Lodise 2007 & Yes & Yes & Yes & Yes & Yes & Yes & Yes & Yes & Yes & 9 \\
\hline Patel 2009 & Yes & Yes & Yes & Yes & Yes & Yes & Yes & Yes & Yes & 9 \\
\hline Lorente 2009 & Yes & Yes & Yes & Yes & Yes & Yes & Yes & Yes & Yes & 9 \\
\hline Robort 2010 & Yes & Yes & Yes & Yes & Yes & Yes & Yes & Yes & Yes & 9 \\
\hline Yost 2011 & Yes & Yes & Yes & Yes & Yes & Yes & Yes & Yes & Yes & 9 \\
\hline Pereira 2012 & Yes & Yes & Yes & Yes & Yes & Yes & Yes & Yes & Yes & 9 \\
\hline Lee 2012 & Yes & Yes & Yes & Yes & Yes & Yes & Yes & Yes & Yes & 9 \\
\hline Cutro 2014 & Yes & Yes & Yes & Yes & Yes & Yes & Yes & Yes & Yes & 9 \\
\hline McCormick 2015 & Yes & Yes & Yes & Yes & Yes & Yes & Yes & Yes & Yes & 9 \\
\hline Brunetti 2015 & Yes & Yes & Yes & Yes & Yes & Yes & Yes & Yes & Yes & 9 \\
\hline \multicolumn{11}{|c|}{$\begin{array}{l}\text { a. Indicates exposed cohort truly representative } \\
\text { b. Non-exposed cohort drawn from the same community } \\
\text { c. Ascertainment of exposure from the same community } \\
\text { d. Outcome of interest not present at start of study } \\
\text { e. Cohorts comparable on basis of site and etiology of infection } \\
\text { f. Cohorts comparable on others factors } \\
\text { g. Assessment of outcome of record linkage or independent blind assessment } \\
\text { h. Follow-up long enough for outcomes to occur. } \\
\text { i. Complete accounting for cohorts }\end{array}$} \\
\hline
\end{tabular}


J Pharm Pharm Sci (www.cspsCanada.org) 19(2) 274 - 289, 2016

Table 1. The characteristics of included studies

\begin{tabular}{|c|c|c|c|c|c|c|c|c|c|c|c|c|c|c|c|c|c|c|c|}
\hline \multirow[t]{2}{*}{ Author, year, reference } & \multirow{2}{*}{$\begin{array}{l}\text { Study } \\
\text { design; } \\
\text { years, } \\
\text { country }\end{array}$} & \multirow{2}{*}{$\begin{array}{l}\text { No. } \\
\text { infe } \\
\text { ctio } \\
\text { ns }\end{array}$} & \multirow[t]{2}{*}{$\begin{array}{c}\text { CI or } \\
\text { EI }\end{array}$} & \multirow[t]{2}{*}{ II } & \multicolumn{3}{|c|}{ Clinical cure } & \multicolumn{3}{|c|}{ Mortality } & \multicolumn{3}{|c|}{$\begin{array}{l}\text { Bacteriologic } \\
\text { cure }\end{array}$} & \multicolumn{3}{|c|}{$\begin{array}{l}\text { Length of } \\
\text { hospital stay }\end{array}$} & \multicolumn{3}{|l|}{ Cost } \\
\hline & & & & & $\begin{array}{l}\mathrm{CI} \\
\mathrm{n} / \mathrm{N} \\
(\%)\end{array}$ & $\begin{array}{l}\mathrm{II}, \\
\mathrm{n} / \mathrm{N} \\
(\%)\end{array}$ & $\begin{array}{l}\text { P } \\
\text { va } \\
\text { lu } \\
\text { e }\end{array}$ & $\begin{array}{l}\mathrm{CI} \\
\mathrm{n} / \mathrm{N} \\
(\%)\end{array}$ & $\begin{array}{l}\mathrm{II}, \\
\mathrm{n} / \mathrm{N} \\
(\%)\end{array}$ & $\begin{array}{l}\text { Pv } \\
\text { al } \\
\text { ue }\end{array}$ & $\begin{array}{l}\text { CI, } \\
\mathrm{n} / \mathrm{N} \\
(\%)\end{array}$ & $\begin{array}{l}\mathrm{II}, \\
\mathrm{n} / \mathrm{N} \\
(\%)\end{array}$ & $\begin{array}{l}\text { P } \\
\text { va } \\
\text { lv } \\
\text { e }\end{array}$ & CI & II & $\begin{array}{l}\mathrm{Pv} \\
\text { al } \\
\text { ue }\end{array}$ & $\mathrm{CI}$ & II & $\begin{array}{l}\mathrm{Pv} \\
\text { alu } \\
\mathrm{e}\end{array}$ \\
\hline Grant,2002,[16] & $\begin{array}{l}\text { Prospecti } \\
\text { ve, open- } \\
\text { lable } \\
\text { controlle } \\
\text { d } \\
\text { trail;199 } \\
9-2000, \\
\text { USA }\end{array}$ & $\begin{array}{l}98, \\
\text { all } \\
\text { type } \\
\text { s of } \\
\text { infe } \\
\text { ctio } \\
n\end{array}$ & $\begin{array}{l}9 \mathrm{~g} \\
\mathrm{q} 24 \mathrm{~h} \\
\text { for } \\
\text { HAP( } \\
\mathrm{n}=24) \text {, } \\
13.5 \mathrm{~g} \\
\mathrm{q} 24 \mathrm{~h} \\
\text { for } \\
\text { nosoc } \\
\text { omial } \\
\text { infecti } \\
\text { ons(n= } \\
23)\end{array}$ & $\begin{array}{l}3.375 \\
\mathrm{q} 6 \mathrm{~h}(\mathrm{n} \\
=2), 4 . \\
5 \mathrm{~g} \\
\mathrm{q} 8 \mathrm{~h}(\mathrm{n} \\
=49)\end{array}$ & $\begin{array}{l}44 / 47 \\
(94)\end{array}$ & $\begin{array}{l}42 / 51 \\
(82)\end{array}$ & $\begin{array}{l}0 . \\
0 \\
8 \\
1\end{array}$ & $\begin{array}{l}1 / 47( \\
2.1)\end{array}$ & $\begin{array}{l}5 / 51( \\
9.8)\end{array}$ & $\begin{array}{l}> \\
0 . \\
5\end{array}$ & $\begin{array}{l}25 / 2 \\
8(89 \\
)\end{array}$ & $\begin{array}{l}23 / 3 \\
2(73 \\
)\end{array}$ & $\begin{array}{l}0 . \\
0 \\
9 \\
2\end{array}$ & $\begin{array}{l}7.3 \pm \\
4.8\end{array}$ & $\begin{array}{l}8.7 \pm \\
7.1\end{array}$ & $\begin{array}{l}0 . \\
26\end{array}$ & $\begin{array}{l}\$ 399.3 \\
8 \pm 407 \\
.22\end{array}$ & $\begin{array}{l}\$ 523.4 \\
9 \pm 526 \\
.85\end{array}$ & $\begin{array}{l}0.0 \\
28\end{array}$ \\
\hline Buck,2005,[17] & $\begin{array}{l}\text { Prospecti } \\
\text { ve, } \\
\text { randomiz } \\
\text { ed } \\
\text { clinical } \\
\text { observati } \\
\text { onal } \\
\text { trial;NR, } \\
\text { Germany }\end{array}$ & $\begin{array}{l}24, \\
\mathrm{CA} \\
\mathrm{P} \text { or } \\
\mathrm{HA} \\
\mathrm{P}\end{array}$ & $\begin{array}{l}9 \mathrm{~g} \\
\mathrm{q} 12 \mathrm{~h}( \\
\mathrm{n}=12)^{\mathrm{a}}\end{array}$ & $\begin{array}{l}4.5 \mathrm{~g} \\
\mathrm{q} 8 \mathrm{~h}(\mathrm{n} \\
=12)\end{array}$ & $\begin{array}{l}8 / 12( \\
67)\end{array}$ & $\begin{array}{l}8 / 12( \\
67)\end{array}$ & $\begin{array}{l}> \\
0 . \\
0 \\
5\end{array}$ & NR & NR & $\begin{array}{l}\mathrm{N} \\
\mathrm{R}\end{array}$ & NR & NR & $\begin{array}{l}\mathrm{N} \\
\mathrm{R}\end{array}$ & NR & NR & $\begin{array}{l}\mathrm{N} \\
\mathrm{R}\end{array}$ & NR & NR & $\begin{array}{l}\mathrm{N} \\
\mathrm{R}\end{array}$ \\
\hline Lau,2006,[28] & $\begin{array}{l}\text { RCT, } \\
\text { open- } \\
\text { lable;200 } \\
2- \\
2004, U S \\
\text { A }\end{array}$ & $\begin{array}{l}167, \\
\text { cIAI } \\
\mathrm{s}\end{array}$ & $\begin{array}{l}13.5 \mathrm{~g} \\
q 24 h( \\
n=130 \\
)^{b}\end{array}$ & $\begin{array}{l}3.375 \\
\mathrm{~g} \\
\text { over } \\
30 \mathrm{mi} \\
\mathrm{n} \\
\mathrm{q} 6 \mathrm{~h}(\mathrm{n} \\
=132)\end{array}$ & $\begin{array}{l}70 / 81 \\
(86)\end{array}$ & $\begin{array}{l}76 / 86 \\
(88)\end{array}$ & $\begin{array}{l}0 . \\
8 \\
1 \\
7\end{array}$ & $\begin{array}{l}1 / 13 \\
0(0.8 \\
)\end{array}$ & $\begin{array}{l}3 / 13 \\
2(2.3 \\
)\end{array}$ & $\begin{array}{l}> \\
0 . \\
05\end{array}$ & $\begin{array}{l}47 / 5 \\
6(83 \\
.9)\end{array}$ & $\begin{array}{l}51 / 5 \\
8(87 \\
.9)\end{array}$ & $\begin{array}{l}0 . \\
5 \\
9 \\
7\end{array}$ & NR & NR & $\begin{array}{l}\mathrm{N} \\
\mathrm{R}\end{array}$ & NR & NR & $\begin{array}{l}\mathrm{N} \\
\mathrm{R}\end{array}$ \\
\hline Rafati,2006,[29] & $\begin{array}{l}\text { RCT;200 } \\
3- \\
2004, \text { Ira }\end{array}$ & $\begin{array}{l}40, \\
\text { ICU } \\
\text { sept }\end{array}$ & $\begin{array}{l}8 \mathrm{~g} \\
\text { daily } \\
\text { over }\end{array}$ & $\begin{array}{l}3 \mathrm{~g} \\
\text { over } \\
0.5 \mathrm{~h}\end{array}$ & NR & NR & $\begin{array}{l}\mathrm{N} \\
\mathrm{R}\end{array}$ & $\begin{array}{l}5 / 20( \\
25)\end{array}$ & $\begin{array}{l}6 / 20( \\
30)\end{array}$ & $\begin{array}{l}0 . \\
72\end{array}$ & NR & NR & $\begin{array}{l}\mathrm{N} \\
\mathrm{R}\end{array}$ & $\begin{array}{l}1.7 \pm \\
0.7\end{array}$ & $\begin{array}{l}2.4 \pm \\
1.5\end{array}$ & $\begin{array}{l}0 . \\
08\end{array}$ & NR & NR & $\begin{array}{l}\mathrm{N} \\
\mathrm{R}\end{array}$ \\
\hline
\end{tabular}


J Pharm Pharm Sci (www.cspsCanada.org) 19(2) 274 - 289, 2016

\begin{tabular}{|c|c|c|c|c|c|c|c|c|c|c|c|c|c|c|c|c|c|c|c|}
\hline & $\mathrm{n}$ & ic & $\begin{array}{l}24 \mathrm{~h} \\
\mathrm{~g}(\mathrm{n}=2 \\
0)^{\mathrm{c}}\end{array}$ & $\begin{array}{l}\text { q6h(n } \\
=20)\end{array}$ & & & & & & & & & & & & & & & \\
\hline Lodise,2007,[18] & $\begin{array}{l}\text { Retrospe } \\
\text { ctive } \\
\text { cohort;2 } \\
000- \\
\text { 2004,US } \\
\text { A }\end{array}$ & 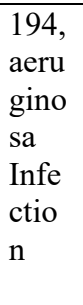 & $\begin{array}{l}3.375 \mathrm{~g} \\
\text { over } \\
4 \mathrm{~h}, \mathrm{q} 8 \mathrm{~h} \\
(\mathrm{n}=10 \\
2)^{\mathrm{d}}\end{array}$ & $\begin{array}{l}3.375 \\
\text { over } \\
30 \mathrm{mi} \\
\mathrm{n}, \\
\mathrm{q} 4 \mathrm{~h} \\
\text { or } \\
\mathrm{q} 6 \mathrm{~h}(\mathrm{n} \\
=92)\end{array}$ & NR & NR & $\begin{array}{l}\mathrm{N} \\
\mathrm{R}\end{array}$ & $\begin{array}{l}5 / 41( \\
12.2)\end{array}$ & $\begin{array}{l}12 / 3 \\
8(31 . \\
6)\end{array}$ & $\begin{array}{l}0 . \\
04\end{array}$ & NR & NR & $\begin{array}{l}\mathrm{N} \\
\mathrm{R}\end{array}$ & NR & NR & $\begin{array}{l}\mathrm{N} \\
\mathrm{R}\end{array}$ & NR & NR & $\begin{array}{l}\mathrm{N} \\
\mathrm{R}\end{array}$ \\
\hline Patel,2009,[19] & $\begin{array}{l}\text { Retrospe } \\
\text { ctive } \\
\text { cohort;2 } \\
006- \\
\text { 2007,US } \\
\text { A }\end{array}$ & $\begin{array}{l}129, \\
\text { Gra } \\
\mathrm{m}(-) \\
\text { infe } \\
\text { ctio } \\
\mathrm{n}\end{array}$ & $\begin{array}{l}3.375 \mathrm{~g} \\
\text { over } \\
4 \mathrm{~h}, \mathrm{q} 8 \mathrm{~h} \\
(\mathrm{n}=70)\end{array}$ & $\begin{array}{l}3.375 \\
\text { to } \\
4.5 \mathrm{~g} \\
\text { over } \\
30 \mathrm{mi} \\
\mathrm{n} \mathrm{q} 6 \mathrm{~h} \\
\text { or } \\
\mathrm{q} 8 \mathrm{~h}(\mathrm{n} \\
=59)\end{array}$ & NR & NR & $\begin{array}{l}\mathrm{N} \\
\mathrm{R}\end{array}$ & $\begin{array}{l}4 / 70( \\
5.7)\end{array}$ & $\begin{array}{l}5 / 59( \\
8.5)\end{array}$ & $\begin{array}{l}0 . \\
54\end{array}$ & NR & NR & $\begin{array}{l}\mathrm{N} \\
\mathrm{R}\end{array}$ & NR & NR & $\begin{array}{l}\mathrm{N} \\
\mathrm{R}\end{array}$ & NR & NR & $\begin{array}{l}\mathrm{N} \\
\mathrm{R}\end{array}$ \\
\hline Lorente,2009,[20] & $\begin{array}{l}\text { Retrospe } \\
\text { ctive } \\
\text { cohort; } 2 \\
002- \\
2007, \text { Spa } \\
\text { in }\end{array}$ & $\begin{array}{l}83, \\
\text { vent } \\
\text { ilato } \\
\text { r- } \\
\text { asso } \\
\text { ciat } \\
\text { ed } \\
\text { pne } \\
\text { umo } \\
\text { nia } \\
\end{array}$ & $\begin{array}{l}4.5 \mathrm{~g} \\
\text { over } \\
6 \mathrm{~h} \\
\mathrm{q} 6 \mathrm{~h}(\mathrm{n} \\
=37)^{\mathrm{e}}\end{array}$ & $\begin{array}{l}4.5 \mathrm{~g} \\
\text { over } \\
30 \mathrm{mi} \\
\mathrm{n} \\
\mathrm{q} 6 \mathrm{~h}(\mathrm{n} \\
=46)\end{array}$ & $\begin{array}{l}33 / 37 \\
(89.2 \\
)\end{array}$ & $\begin{array}{l}26 / 46 \\
(56.2 \\
)\end{array}$ & $\begin{array}{l}0 . \\
0 \\
0 \\
1\end{array}$ & $\begin{array}{l}8 / 37( \\
21.6)\end{array}$ & $\begin{array}{l}14 / 4 \\
6(30 . \\
4)\end{array}$ & $\begin{array}{l}0 . \\
46\end{array}$ & NR & NR & $\begin{array}{l}\mathrm{N} \\
\mathrm{R}\end{array}$ & $\begin{array}{l}21.8 \\
1 \pm 12 \\
.34\end{array}$ & $\begin{array}{l}25.6 \\
1 \pm 19 \\
.84\end{array}$ & $\begin{array}{l}0 . \\
62\end{array}$ & NR & NR & $\begin{array}{l}\mathrm{N} \\
\mathrm{R}\end{array}$ \\
\hline Robort,2010,[21] & $\begin{array}{l}\text { Retrospe } \\
\text { ctive;200 } \\
\text { 5,Austral } \\
\text { ia }\end{array}$ & $\begin{array}{l}16, \\
\text { seps } \\
\text { is }\end{array}$ & $\begin{array}{l}13.5 \\
\text { contin } \\
\text { uous(n } \\
=8)\end{array}$ & $\begin{array}{l}4.5 \mathrm{~g} \\
\text { over } \\
20 \mathrm{mi} \\
\mathrm{n} \mathrm{q} 6 \mathrm{~h} \\
\text { or } \\
\mathrm{q} 8 \mathrm{~h}(\mathrm{n} \\
=8)\end{array}$ & $\begin{array}{l}8 / 8(1 \\
00)\end{array}$ & $\begin{array}{l}8 / 8(1 \\
00)\end{array}$ & $\begin{array}{l}\mathrm{N} \\
\mathrm{R}\end{array}$ & $\begin{array}{l}0 / 8(0 \\
)\end{array}$ & $\begin{array}{l}0 / 8(0 \\
)\end{array}$ & $\begin{array}{l}\mathrm{N} \\
\mathrm{R}\end{array}$ & NR & NR & $\begin{array}{l}\mathrm{N} \\
\mathrm{R}\end{array}$ & NR & NR & $\begin{array}{l}\mathrm{N} \\
\mathrm{R}\end{array}$ & NR & NR & $\begin{array}{l}\mathrm{N} \\
\mathrm{R}\end{array}$ \\
\hline Yost,2011,[22] & $\begin{array}{l}\text { Retrospe } \\
\text { ctive } \\
\text { Cohort;2 }\end{array}$ & $\begin{array}{l}359, \\
\text { gra } \\
\text { m- }\end{array}$ & $\begin{array}{l}3.375 \mathrm{~g} \\
\text { over } \\
4 \mathrm{~h}\end{array}$ & $\begin{array}{l}\text { NR(n } \\
=84)\end{array}$ & NR & NR & $\begin{array}{l}\mathrm{N} \\
\mathrm{R}\end{array}$ & $\begin{array}{l}18 / 1 \\
86(9 . \\
7)\end{array}$ & $\begin{array}{l}17 / 8 \\
4(20 . \\
2)\end{array}$ & $\begin{array}{l}0 . \\
03\end{array}$ & NR & NR & $\begin{array}{l}\mathrm{N} \\
\mathrm{R}\end{array}$ & NR & NR & $\begin{array}{l}\mathrm{N} \\
\mathrm{R}\end{array}$ & NR & NR & $\begin{array}{l}\mathrm{N} \\
\mathrm{R}\end{array}$ \\
\hline
\end{tabular}


J Pharm Pharm Sci (www.cspsCanada.org) 19(2) 274 - 289, 2016

\begin{tabular}{|c|c|c|c|c|c|c|c|c|c|c|c|c|c|c|c|c|c|c|c|}
\hline & $\begin{array}{l}007- \\
2010, \mathrm{US} \\
\text { A }\end{array}$ & $\begin{array}{l}\text { neg } \\
\text { ativ } \\
\text { e } \\
\text { infe } \\
\text { ctio } \\
\text { ns }\end{array}$ & $\begin{array}{l}\mathrm{q} 8 \mathrm{~h}(\mathrm{n} \\
=186)\end{array}$ & & & & & & & & & & & & & & & & \\
\hline Pereira,2012,[23] & $\begin{array}{l}\text { Retrospe } \\
\text { ctive } \\
\text { cohort;2 } \\
\text { 006- } \\
\text { 2010,Por } \\
\text { tugal }\end{array}$ & $\begin{array}{l}346, \\
\text { ICU } \\
\text { seps } \\
\text { is }\end{array}$ & $\begin{array}{l}\text { NR(n= } \\
173)\end{array}$ & $\begin{array}{l}\mathrm{t}=30 \\
\min , \mathrm{d} \\
\text { ose } \\
\mathrm{NR}(\mathrm{n} \\
=173)\end{array}$ & NR & NR & $\begin{array}{l}\mathrm{N} \\
\mathrm{R}\end{array}$ & $\begin{array}{l}49 / 1 \\
73(2 \\
8.3)\end{array}$ & $\begin{array}{l}49 / 1 \\
73(2 \\
8.3)\end{array}$ & $\begin{array}{l}1 . \\
0\end{array}$ & NR & NR & $\begin{array}{l}\mathrm{N} \\
\mathrm{R}\end{array}$ & NR & NR & $\begin{array}{l}\mathrm{N} \\
\mathrm{R}\end{array}$ & NR & NR & $\begin{array}{l}\mathrm{N} \\
\mathrm{R}\end{array}$ \\
\hline Lee,2012,[24] & $\begin{array}{l}\text { Retrospe } \\
\text { ctive;200 } \\
9- \\
\text { 2011,US } \\
\text { A }\end{array}$ & $\begin{array}{l}148, \\
\text { ICU } \\
\text { gra } \\
\text { m- } \\
\text { neg } \\
\text { ativ } \\
\text { e } \\
\text { infe } \\
\text { ctio } \\
\text { n }\end{array}$ & $\begin{array}{l}3.375 \mathrm{~g} \\
\text { over4h } \\
\mathrm{q} 8 \mathrm{~h}(\mathrm{n} \\
=68)\end{array}$ & $\begin{array}{l}2.25- \\
4.5 \mathrm{~g} \\
\text { over } \\
30 \mathrm{mi} \\
\mathrm{n} \mathrm{q} 6 \mathrm{~h} \\
\text { or } \\
\mathrm{q} 8 \mathrm{~h}(\mathrm{n} \\
=80)\end{array}$ & NR & NR & $\begin{array}{l}\mathrm{N} \\
\mathrm{R}\end{array}$ & $\begin{array}{l}13 / 6 \\
8(19)\end{array}$ & $\begin{array}{l}30 / 8 \\
0(38)\end{array}$ & $\begin{array}{l}0 . \\
01\end{array}$ & NR & NR & $\begin{array}{l}\mathrm{N} \\
\mathrm{R}\end{array}$ & NR & NR & $\begin{array}{l}\mathrm{N} \\
\mathrm{R}\end{array}$ & NR & NR & $\begin{array}{l}\mathrm{N} \\
\mathrm{R}\end{array}$ \\
\hline Lu,2013,[30] & $\begin{array}{l}\text { RCT;201 } \\
\text { 2,China }\end{array}$ & $\begin{array}{l}50, \\
\text { ICU } \\
\text { HA } \\
\mathrm{P}\end{array}$ & $\begin{array}{l}4.5 \mathrm{~g} \\
\text { over } \\
3 \mathrm{~h} \\
\mathrm{q} 6 \mathrm{~h}(\mathrm{n} \\
=25)\end{array}$ & $\begin{array}{l}4.5 \mathrm{~g} \\
\text { over } \\
30 \mathrm{mi} \\
\mathrm{n} \\
\mathrm{q} 6 \mathrm{~h}(\mathrm{n} \\
=25)\end{array}$ & $\begin{array}{l}22 / 25 \\
(88)\end{array}$ & $\begin{array}{l}20 / 25 \\
(80)\end{array}$ & $\begin{array}{l}> \\
0 . \\
0 \\
5\end{array}$ & NR & NR & $\begin{array}{l}\mathrm{N} \\
\mathrm{R}\end{array}$ & NR & NR & $\begin{array}{l}\mathrm{N} \\
\mathrm{R}\end{array}$ & $\begin{array}{l}6.00 \\
\pm 1.0 \\
5\end{array}$ & $\begin{array}{l}8.20 \\
\pm 1.0 \\
3\end{array}$ & $\begin{array}{l}<0 \\
.0 \\
5\end{array}$ & $\begin{array}{l}\$ 689.5 \\
4 \pm 173 \\
.89\end{array}$ & $\begin{array}{l}\$ 876.7 \\
7 \pm 216 \\
.83\end{array}$ & $\begin{array}{l}<0 \\
.05\end{array}$ \\
\hline Cutro, 2014,[25] & $\begin{array}{l}\text { Retrospe } \\
\text { ctive;200 } \\
9- \\
2011, \mathrm{US} \\
\text { A }\end{array}$ & $\begin{array}{l}843, \\
\text { seps } \\
\text { is } \\
\text { syn } \\
\text { dro } \\
\text { mes }\end{array}$ & $\begin{array}{l}2.25- \\
3.375 \mathrm{~g} \\
\text { over } \\
4 \mathrm{~h} \text { q6h } \\
\text { or } \\
\mathrm{q} 12 \mathrm{~h}( \\
\mathrm{n}=662 \\
)\end{array}$ & $\begin{array}{l}2.25- \\
4.5 \\
\text { over } \\
30 \mathrm{mi} \\
\mathrm{n} \mathrm{q} 8 \mathrm{~h} \\
\text { or } \\
\mathrm{q} 12 \mathrm{~h}( \\
\mathrm{n}=18 \\
1)\end{array}$ & $\begin{array}{l}540 / 6 \\
62(81 \\
.6)\end{array}$ & $\begin{array}{l}145 / 1 \\
81(80 \\
.1)\end{array}$ & $\begin{array}{l}0 . \\
7 \\
5 \\
6\end{array}$ & $\begin{array}{l}72 / 6 \\
62(1 \\
0.9)\end{array}$ & $\begin{array}{l}25 / 1 \\
81(1 \\
3.8)\end{array}$ & $\begin{array}{l}0 . \\
28 \\
2\end{array}$ & NR & NR & $\begin{array}{l}\mathrm{N} \\
\mathrm{R}\end{array}$ & NR & NR & $\begin{array}{l}\mathrm{N} \\
\mathrm{R}\end{array}$ & NR & NR & $\begin{array}{l}\mathrm{N} \\
\mathrm{R}\end{array}$ \\
\hline McCormick,2015[26] & $\begin{array}{l}\text { Retrospe } \\
\text { ctive;201 } \\
0, \mathrm{USA}\end{array}$ & $\begin{array}{l}200, \\
\text { all } \\
\text { type }\end{array}$ & $\begin{array}{l}3.375 \mathrm{~g} \\
\text { over } \\
4 \mathrm{~h} \mathrm{q} 8 \mathrm{~h} \\
\end{array}$ & $\begin{array}{l}2.25- \\
4.5 \mathrm{~g} \\
\text { over } \\
\end{array}$ & NR & NR & $\begin{array}{l}\mathrm{N} \\
\mathrm{R}\end{array}$ & NR & NR & $\begin{array}{l}\mathrm{N} \\
\mathrm{R}\end{array}$ & NR & NR & $\begin{array}{l}\mathrm{N} \\
\mathrm{R}\end{array}$ & 18.5 & 15.6 & $\begin{array}{l}0 . \\
08 \\
3 \\
\end{array}$ & NR & NR & $\begin{array}{l}\mathrm{N} \\
\mathrm{R}\end{array}$ \\
\hline
\end{tabular}


J Pharm Pharm Sci (www.cspsCanada.org) 19(2) 274 - 289, 2016

\begin{tabular}{|c|c|c|c|c|c|c|c|c|c|c|c|c|c|c|c|c|c|c|c|}
\hline & & $\begin{array}{l}\text { s of } \\
\text { infe } \\
\text { ctio } \\
n\end{array}$ & $\begin{array}{l}\text { or } \\
q 12 h( \\
n=100 \\
)\end{array}$ & $\begin{array}{l}30 \\
\min \\
\mathrm{q} 6 \mathrm{~h} \\
\text { or } \\
\mathrm{q} 8 \mathrm{~h}(\mathrm{n} \\
=100)\end{array}$ & & & & & & & & & & & & & & & \\
\hline Brunetti，2015,[27] & $\begin{array}{l}\text { Retrospec } \\
\text { tive;2009- } \\
\text { 2012,UA } \\
\text { S }\end{array}$ & $\begin{array}{l}2150 \\
, \quad \text { all } \\
\text { type } \\
\text { s of } \\
\text { infec } \\
\text { tion }\end{array}$ & $\begin{array}{l}3.375 \mathrm{~g} \\
\text { over } 4 \mathrm{~h} \\
\mathrm{q} 8- \\
12 \mathrm{~h}(\mathrm{n}= \\
632)\end{array}$ & $\begin{array}{l}2.25 \mathrm{~g}, \\
3.375 \\
\mathrm{~g}, \quad \text { or } \\
4.5 \mathrm{~g} \\
\text { over } \\
30 \mathrm{~min} \\
\mathrm{q} 6- \\
8 \mathrm{~h}(15 \\
18)\end{array}$ & NR & NR & $\begin{array}{l}\mathrm{N} \\
\mathrm{R}\end{array}$ & $\begin{array}{l}67 / 63 \\
2(10 . \\
6)\end{array}$ & $\begin{array}{l}141 / 1 \\
518(9 \\
.3)\end{array}$ & $\begin{array}{l}0.3 \\
7\end{array}$ & NR & NR & $\begin{array}{l}\mathrm{N} \\
\mathrm{R}\end{array}$ & $\begin{array}{l}12.5 \pm \\
9.5\end{array}$ & $\begin{array}{l}11.8 \pm \\
9.5\end{array}$ & 0.1 & $\begin{array}{l}\$ 565.9 \\
0 \pm 257 \\
70\end{array}$ & $\begin{array}{l}\$ 648.3 \\
0 \pm 349 \\
20\end{array}$ & $\begin{array}{l}<0 . \\
00 \\
01\end{array}$ \\
\hline \multicolumn{20}{|c|}{$\begin{array}{l}\text { CI, Continuous infusion; EI, Extended infusion; II, Intermittent infusion; CAP, Community acquired pneumonia; HAP, Hospital acquired pneumonia; cIAIs, Complicated intra-abdominal infection; } \\
\text { ICU, Intensive care unit; CCU, Critical care unit; VAP, Ventilator-associated pneumonia. } \\
\text { a. 2.5g single loading dose before starting continuous infusion. } \\
\text { b. A loading dose was administered before continuous infusion: } 2.25 \mathrm{~g} \text { over } 30 \mathrm{~min} \text {. } \\
\text { c. Loading dose was administered before continuous infusion: } 2 \mathrm{~g} \text {. } \\
\text { d. Among patients with Acute Physiological and Chronic Health Evaluation-II score } \geq 17 \text {. } \\
\text { e. A loading dose was administered before continuous infusion: } 4.5 \mathrm{~g} \text { over } 30 \mathrm{~min} \text {. A loading dose was administered before continuous infusion. }\end{array}$} \\
\hline
\end{tabular}

